Our Nature (2013), 11(1): 36-44

\title{
Distributional Patterns of Benthic Macro-invertebrate Fauna in the Glacier Fed Rivers of Indian Himalaya
}

\author{
Asheesh Shivam Mishra ${ }^{1^{*}}$, Prakash Nautiyal ${ }^{1}$ and Vijay Prakash Semwal ${ }^{2}$ \\ ${ }^{1}$ Aquatic Biodiversity Unit, Department of Zoology and Biotechnology, H.N.B. Garhwal University, \\ Srinagar - 246174, Uttarakhand, India \\ ${ }^{2}$ Department of Zoology, Govt. P.G. College, New Tehri, Uttarakhand, India \\ *E-mail:drasmhnbgu@yahoo.com
}

Received: 05.04.2012, Accepted: 12.06.2013

\begin{abstract}
Large-scale distributional pattern for the benthic macro-invertebrate fauna was determined in the glacier fed Himalayan and Trans-Himalayan rivers and streams of India at the elevation range of $2000-3000 \mathrm{~m}$ asl. In Trans-Himalaya the family Heptageniidae (Ephemeroptera) alone (Chandra and Bhaga) or in combination with Chironomidae (Diptera) in similar proportions (Chenab) or Diptera alone (Miyar) dominated the assemblages. Its influence seems to extend to Rupin drainage in the Himalaya where Chironomidae alone dominated the assemblages. Except for this Himalayan river. Various families of Trichoptera attained highest abundance in other rivers of the Himalaya. Thus, Leptoceridae in combination with Limnephilidae (Alaknanada at Tapovan) and Heptageniidae and Baetidae (Alaknanada at Mana) is the only instance of similarity in abundant taxa by virtue of same river. The Mandakini was partially similar to Alaknanda by virtue of abundant Limnephilidae. The Bhagirathi was characterized by abundance of Philopotamidae. Thus, assemblages exhibit greater variability in the Himalayan rivers than Trans-Himalayan rivers and are hence entirely different, as also evident from the cluster analysis. This present hypothesis is not applicable to explain the macro-invertebrate assemblages in Himalayan and Trans-Himalayan region.
\end{abstract}

Key words: Biome, Chenab, High elevation, Himalaya, Insects, Rupin

\section{Introduction}

During the past three decades, concepts of the structure and function of stream, ecosystems developed vigorously (Allan, 1959; Ross, 1963; Pahwa, 1979; Vannote et al., 1980; Corkum, 1989). The benthic macro-invertebrate distribution was primarily related to the organic energy base, as well as to habitat or biotope preferences (Culp and Davis, 1982; Cushing et al., 1983; Wallace, 1988). The knowledge regarding distribution of benthic macro invertebrate fauna in river ecosystems of India is limited and highly fragmentary viz., in the Chambal river (Khan and Kulshrestha, 1993), the Khan (Kulshrestha et al., 1989), the Ken (Nautiyal and Mishra, 2012; 2013), the Paisuni (Mishra and Nautiyal, 2011), the Tons (Mishra and Nautiyal, 2013), the Cauvery (Sivaramakrishnan et al., 1995). In the case of Himalaya too, the knowledge is limited to localities or for certain sections of the river in the lesser 


\section{Asheesh Shivam Mishra, Prakash Nautiyal and Vijay Prakash Semwal \\ / Our Nature (2013) 11(1): 36-44}

Himalaya; the Ganga river system (Badola and Singh, 1981; Singh and Nautiyal, 1990; Singh et al., 1994; Gusain, 1994; Nautiyal et al., 1997; Sunder, 1997), Satluj (Julka et al., 1999), Jhelum (Engblom and Lingdell, 1999) and Nepal Himalaya (Ormerod et al., 1994). The local and regional patterns of distribution of macro-invertebrate fauna close to the snow line or in the Greater or Trans-Himalaya have been scarcely investigated; Mandakini basin (Semwal and Nautiyal, 2009). In view of this, preliminary efforts were made to investigate the largescale distributional patterns and taxonomic composition of benthic macro-invertebrate communities in the rivers of two adjoining zones of Himalaya; Trans-Himalaya (Himachal Pradesh) and Himalaya (Uttarakhand). The study proposes to classify the Trans-Himalaya and Himalaya rivers/ locations on the basis of distribution of the macro-invertebrate fauna and examine suitability of 'biome dependency hypothesis' (based on family level) to explain large scale distributional patterns in these regions.

\section{Materials and methods}

The present study was restricted to some rivers at several locations ranging in elevation from 2000-3000 $\mathrm{m}$ asl in the Himalaya (Alaknanda, Bhagirathi, Mandakini, Rupin) and Trans-Himalaya (Chandra, Bhaga, Miyar, Chenab) of India. The fauna was sampled seasonally (10 quadrates per stations) in Himalaya during 2005, while Trans-Himalayan streams were sampled intensively (20 quadrates per stations) once in 2011 due to limited access through Rohtang Pass. Total 24 locations were sampled in 8 rivers situated in two different regions of Himalaya (Tab. 1 and Fig. 1). Each river was sampled at different three stations within $200 \mathrm{~m}$ stretch depending on the various microhabitat and velocity. Onetime intensive sampling is considered appropriate to analyze the distributional patterns of benthic macro-invertebrate assemblages, which reflect real difference among the sites and not seasonal trends (Corkum, 1989). Since distributional patterns of species are a function of dispersal mechanism, environmental tolerances and historical factors (Carter et al., 1980), the likelihood of a species being present throughout a large geographical area is low. Sampling procedures at each station involved lifting stones (boulder, cobble, pebble, gravel) and sieving clay and silt from $0.09 \mathrm{~m}^{2}$ area in different flows (turbulent, swift, slow, placid). The substrate was washed to dislodge the fauna, which was preserved in 5\% formalin for further analysis. As broad taxonomic classifications are acceptable when the empirical relationships involving benthic invertebrates are to be developed in a large study area (Corkum, 1989), the fauna was identified to family level (Pennak, 1953; Edmondson, 1959; Edington and Hildrew, 1995). Counts were made to obtain density (indiv. $\mathrm{m}^{-2}$ ), relative abundance (as $\%$ ), the taxonomic composition in each river. The rivers were classified based on their counts using by using Cluster analysis (Wards methods 1-Jacard similarity index measure).

\section{Results}

The relative abundance of Trichoptera is higher in the Himalaya (Mandakini followed by Alaknanda and Bhagirathi) except Diptera in the river Rupin compared with Ephemeroptera in the Trans-Himalaya 
Asheesh Shivam Mishra, Prakash Nautiyal and Vijay Prakash Semwal

/ Our Nature (2013) 11(1): 36-44

Table 1. Geographical co-ordinates and physico-chemical characteristic of the Himalayan and Trans-Himalayan rivers at different sampling locations.

\begin{tabular}{|c|c|c|c|c|c|c|c|c|c|}
\hline Ecoregions & Rivers & Stations & $\begin{array}{l}\text { Latitude } \\
\text { (N) }\end{array}$ & $\begin{array}{l}\text { Longitude } \\
\text { (E) }\end{array}$ & $\begin{array}{l}\text { Altitude } \\
\text { (m) }\end{array}$ & $\begin{array}{l}\text { Substrate } \\
\text { type }\end{array}$ & $\begin{array}{l}\text { WT } \\
\left({ }^{\circ} \mathrm{C}\right)\end{array}$ & $\begin{array}{l}\mathrm{CV} \\
\left(\mathrm{ms}^{-1}\right)\end{array}$ & pH \\
\hline \multirow{5}{*}{ Himalaya } & Alaknanda & Mana & $30^{\circ} 46^{\prime}$ & $79^{\circ} 29^{\prime}$ & 3166 & $\mathrm{R} ; \mathrm{B} ; \mathrm{C}$ & NA & NA & NA \\
\hline & & Tapovan & $30^{\circ} 33^{\prime}$ & $79^{\circ} 33^{\prime}$ & 1637 & $B ; R ; C$ & NA & NA & NA \\
\hline & Bhagirathi & Harsil & $31^{\circ} 02^{\prime}$ & $78^{\circ} 44^{\prime}$ & 2484 & $\mathrm{~B} ; \mathrm{C} ; \mathrm{P}$ & $4.3-9.8$ & $2.0-3.3$ & $7-7.21$ \\
\hline & Mandakini & Sone prayag & $30^{\circ} 37^{\prime}$ & $78^{\circ} 59^{\prime}$ & 1706 & $\mathrm{R} ; \mathrm{B}$ & 9.0 & 1.1 & 7.2 \\
\hline & Rupin & Dodra & $31^{\circ} 14^{\prime}$ & $78^{\circ} 06^{\prime}$ & 2141 & $\mathrm{~B} ; \mathrm{R} ; \mathrm{C}$ & $9.5-10$ & $0.29-0.78$ & $7.6-8.2$ \\
\hline Trans & Miyar & Udaipur & $32^{\circ} 46^{\prime}$ & $76^{\circ} 42^{\prime}$ & 2845 & $\mathrm{R} ; \mathrm{B} ; \mathrm{C}$ & 8.5 & $0.68-2.08$ & $6.7-6.8$ \\
\hline \multirow[t]{3}{*}{ Himalaya } & Chandra & Gondhanala & $32^{\circ} 31^{\prime}$ & $76^{\circ} 38^{\prime}$ & 2891 & $\mathrm{C} ; \mathrm{B} ; \mathrm{P} ; \mathrm{G}$ & 5.4 & 2.6 & $7.5-8.8$ \\
\hline & Bhaga & Tandi & $32^{\circ} 33^{\prime}$ & $76^{\circ} 58^{\prime}$ & 2878 & $\mathrm{~B} ; \mathrm{C} ; \mathrm{P} ; \mathrm{G}$ & 4.8 & 2.5 & 7.7-7.9 \\
\hline & Chenab & Tandi & $32^{\circ} 33^{\prime}$ & $76^{\circ} 58^{\prime}$ & 2879 & $\mathrm{~B} ; \mathrm{C} ; \mathrm{P} ; \mathrm{G}$ & 5.5 & 2.2 & $8.4-8.5$ \\
\hline
\end{tabular}

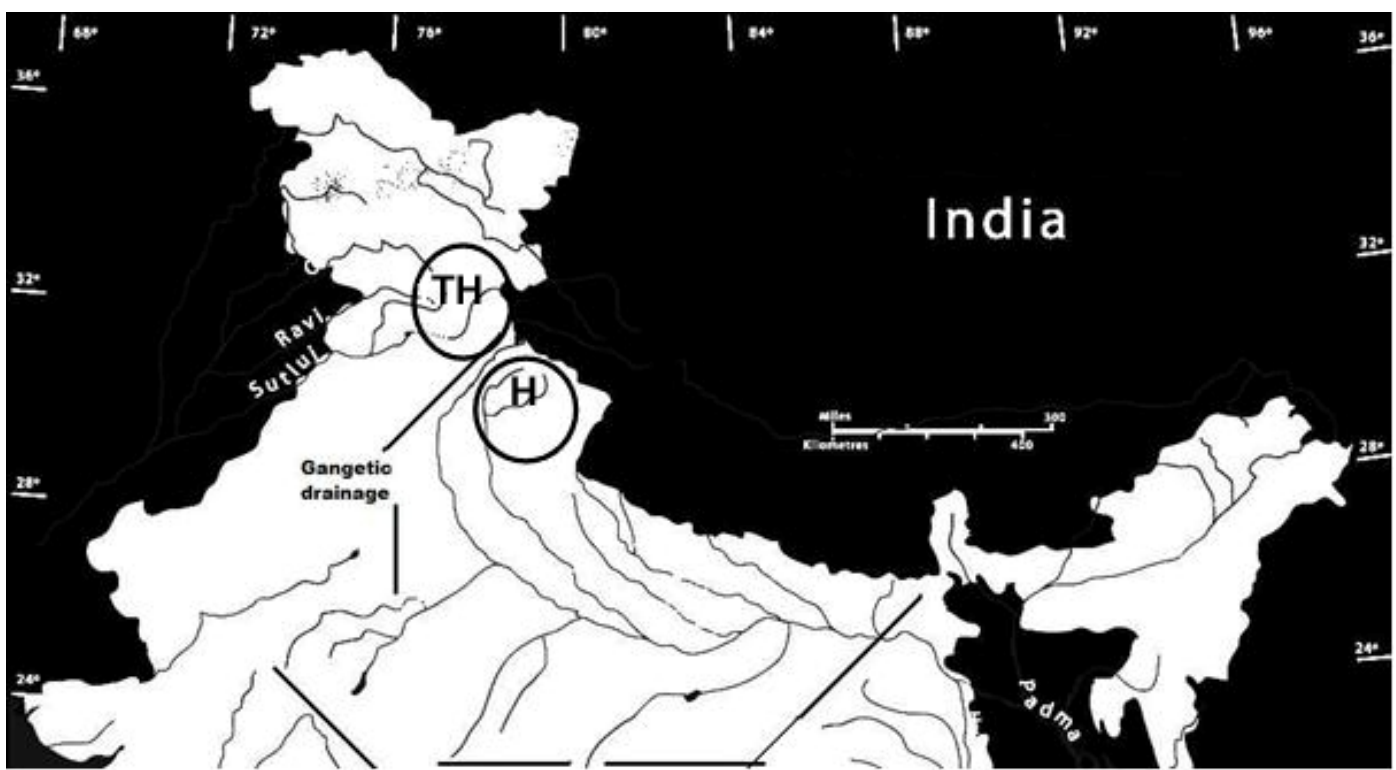

Figure 1. Encircled portion in the map indicates the area of present study in the Himalayan and TransHimalayan Eco-region. $(\mathrm{TH}=$ Trans-Himalaya, $\mathrm{H}=$ Himalaya $)$

(Chenab >, Chandra >, Bhaga > Miyar) (Figs. 2, 3). Ephemeroptera figures as next important macro-invertebrate group in the Himalaya (Fig. 2).

Seven taxa (families) are present in the different rivers/stations of Trans- Himalaya and Himalaya belonging 3 insect orders viz. Ephemeroptera, Trichoptera and Diptera.
Out of these 7 taxa, 2 belong with Ephemeroptera, 3 with Trichoptera and 2 with Diptera (Tab. 2). In the Himalayan rivers, Leptoceridae, Heptageniidae and Baetidae are equally abundant in the river Alaknanda at Mana, and Leptoceridae and Limnephilidae at Tapovan. Philopotamidae is abundant taxon in the Bhagirathi while 


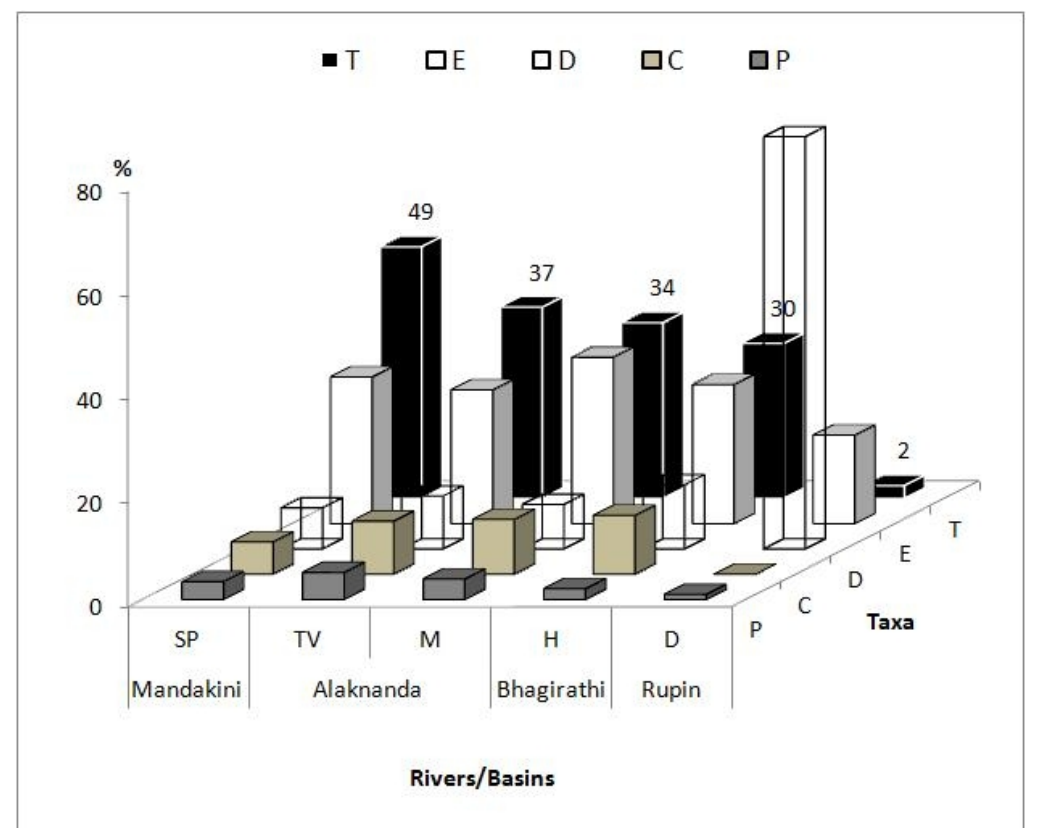

Figure 2. Percentage compositions of dominant taxonomic groups (orders) in the rivers of Himalaya Eco-region. $(\mathrm{SP}=$ Soneprayag, $\mathrm{TV}=$ Tapovan, $\mathrm{M}=$ Mana, $\mathrm{H}=$ Harsil, $\mathrm{D}=$ Dodra $)$

Table 2. Percentage composition of abundant taxa $(>7 \%)$ in the rivers of Trans and Himalaya. The taxa in others category (rest insect fauna and molluscs) are having $<7 \%$ composition.

\begin{tabular}{llllllllll}
\hline Rivers & Stations & HP & BA & PH & LE & LI & CH & SI & Others \\
\hline Himalaya & & & & & & & & & \\
Alknanda & Mana & 8 & 8 & 3 & 8 & 4 & 2 & 2 & 65 \\
& Tapovan & 6 & 8 & 3 & 9 & 9 & 3 & 3 & 59 \\
Bhagirathi & Harsil & 6 & 7 & 8 & 2 & 3 & 3 & 3 & 68 \\
Mandakini & Sonprayag & 7 & 10 & 6 & 5 & 27 & 2 & 2 & 41 \\
Rupin & Dodra & 16 & 1 & - & - & 1 & 27 & 52 & 03 \\
Trans-Himalaya & & & & & & & & & \\
Miyar & Udaipur & 30 & 11 & - & - & - & 33 & 10 & 16 \\
Chadra & Gondhala & 61 & 38 & - & - & - & - & - & 01 \\
Bhaga & Tandi & 47 & 41 & - & - & - & - & - & 12 \\
Chenab & Tandi & 22 & 34 & - & - & - & 34 & - & 10 \\
\hline
\end{tabular}

$(\mathrm{BA}=$ Baetidae, $\mathrm{CH}=$ Chironomidae, $\mathrm{HP}=$ Heptageniidae, $\mathrm{PH}=$ Philopotamidae, $\mathrm{LE}=$ Leptoceridae, $\mathrm{LI}=$ Limnephilidae, SI = Simulidae)

Limnephilidae in Mandakini. In the Rupin, Simulidae was most abundant taxa followed by Chironomidae and Heptageniidae. However, in case of Trans-Himalaya, Chronomid and Heptageniidae are abundant in the Miyar, while Heptageniidae is most abundant in the rivers Chandra and Bhaga (Tab. 2).

Cluster analysis indicates that the rivers under comparison form two major clusters; Himalaya and Trans-Himalaya. However, spatially, all locations group in to 


\section{Asheesh Shivam Mishra, Prakash Nautiyal and Vijay Prakash Semwal \\ / Our Nature (2013) 11(1): 36-44}

two clusters of representing Himalaya and one of the Trans-Himalaya. Among two clusters of the Himalaya one cluster contains some stations of the Miyar nallah in a Trans-Himalayan rivulet.

\section{Discussion}

Ephemeroptera (E), Trichoptera (T), Diptera (D) and Plecoptera (P) are major components of the benthic community (Hynes, 1970; Singh et al., 1994; Nautiyal et al., 2004). In the rivers at higher elevation, these (E, T, D, P) along with coleopteran account for $>80 \%$ of the benthic macro-invertebrate community. These are also known as components of high mountain streams fauna and have been reported in glacial headwaters of the Akbura river the Tien shan Mountains in middle asia at $3670 \mathrm{~m}$ asl despite water temperature $\leq 1.5^{\circ} \mathrm{C}$ (Ward, 1994). The rivers of west Himalaya at higher elevation are glacier fed and dominated by the Trichopterans; Leptoceridae and Limnephilidae in these rivers and they are functionally collectors and scrapers. By virtue of low nutrient concentration near the origin and headwater zone, the algal (primarily diatom) density (Nautiyal et al., 1997) and hence their biomass and the primary production is low. The streams are thus largely heterotrophic in this zone and tend to become autotrophic towards the middle and lower zones near the foothills (Welcomme, 1985; Cotta Ramusino et al., 1995). Headwater streams are heavily influenced by riparian vegetation, which is responsible for large scale inputs of allochthonous nutrients while at the same time hindering autotrophic production by shading (Welcomme, 1985).
Owing to allochthonous nutrients in the headwaters the detritus feeding Trichoptera which function as shredders, gatherers and collectors are predominant. Semwal and Nautiyal (2009) reported equal proportion of Ephemeroptera and Trichoptera in the Kakra Gad at higher elevation (2440 m asl) at headwater zone of the Mandakini basin. This is quite contrary to the observation that the relative abundance of Ephemeroptera exceeds Trichoptera in glacierfed Himalayan rivers; the Bhilangana (Mohan and Bisht, 1991), the Ganga near foothills at Hardwar (Nautiyal et al., 1997), the Bhagirathi (Nautiyal et al., 2007). Ward (1994) also observed that Ephemeroptera proceed Trichoptera in the Alpine glacier fed streams.

In the Trans-Himalayan region, forest is a major land use along with agriculture, village, town and city. The banks of the Trans-Himalayan rivers are devoid of canopy due to lack of dense forest occurs like west Himalaya, which facilitates light penetration leading to increase in periphytonic biomass, thus accounting for abundance of Heptageniidae that function as scrapers. Along with periphyton the fine particulate organic matter is also present in the river due to upstream processing of the coarse particulate organic matters (CPOM; Vannote et al., 1980). Thus, collectors are also present in the river as second abundant components. However, in the Rupin, river banks have canopy, the source of CPOM from vegetation on the slopes. The CPOM converts in to fine particulate organic matters (FPOM) due to instream processing possibly by shredders, thus accounting for the abundance of collectors (Diptera). 


\section{Asheesh Shivam Mishra, Prakash Nautiyal and Vijay Prakash Semwal}

/ Our Nature (2013) 11(1): 36-44

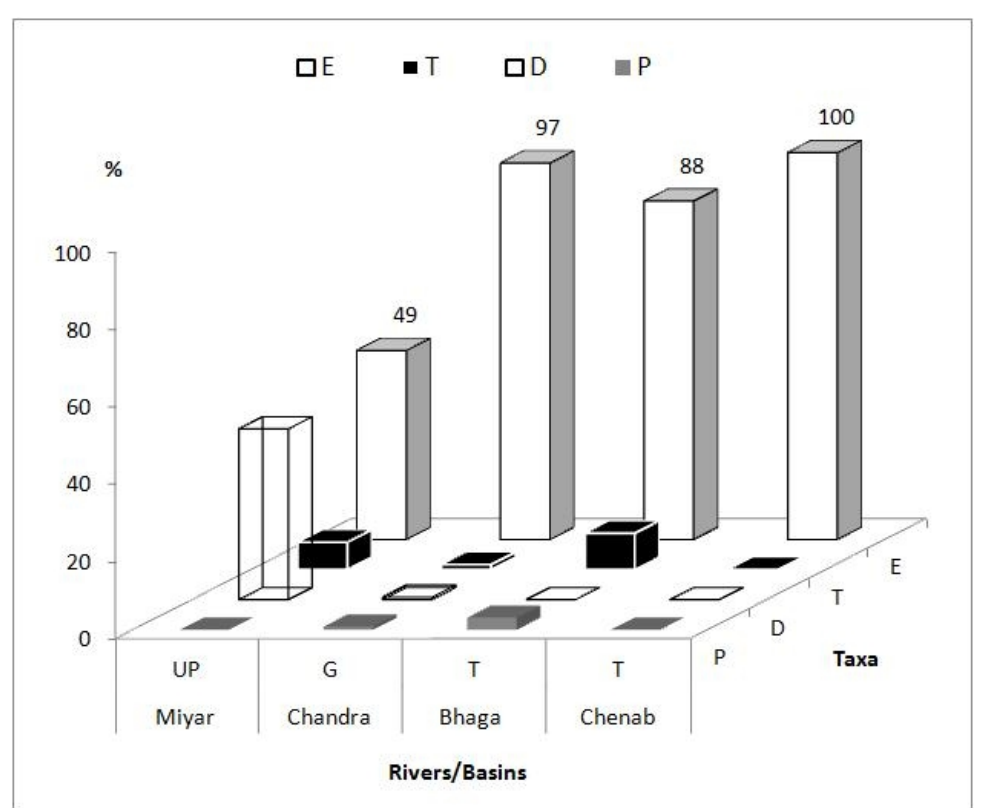

Figure 3. Percentage compositions of dominant taxonomic groups (orders) in the rivers of Trans-Himalaya Ecoregion. $(\mathrm{UP}=$ Udaipur, $\mathrm{G}=$ Gondhala, $\mathrm{T}=$ Tandi $)$

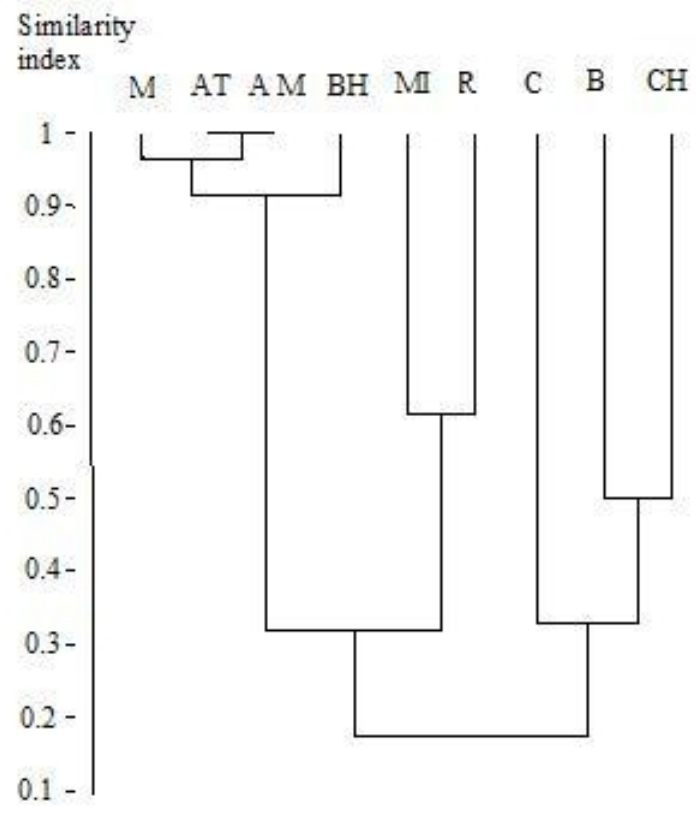

Figure 4. Cluster analysis indicates that the rivers having similar abundant taxa form one group/cluster in the Himalayan and Trans-Himalaya Eco-region. $(\mathrm{M}=$ Mandakini, $\mathrm{AT}=$ Alaknanda-Tapovan, $\mathrm{AM}=$ Alaknanda Mana, $\mathrm{BH}=$ Bhagirathi Harsil, $\mathrm{MI}=$ Miyar, $\mathrm{R}=$ Rupin, $\mathrm{C}=$ Chandra, $\mathrm{B}=$ Bhaga, $\mathrm{CH}=$ Chenab). 


\section{Asheesh Shivam Mishra, Prakash Nautiyal and Vijay Prakash Semwal \\ / Our Nature (2013) 11(1): 36-44}

In Trans-Himalaya the family Heptageniidae (Ephemeroptera) alone (Chandra and Bhaga) or in combination with Chironomidae (Diptera) in similar proportions (Chenab) or Diptera alone (Miyar) dominated the assemblages. Its influence seems to extend to Rupin drainage in the Himalaya where Chironomidae alone dominated the assemblages. Except for this Himalayan river. Various families of Trichoptera attained highest abundance in other rivers of the Himalaya. Thus, Leptoceridae in combination with Limnephilidae (Alaknanada at Tapovan) and Heptageniidae and Baetidae (Alaknanada at Mana) is the only instance of similarity in abundant taxa by virtue of same river. The Mandakini was partially similar to Alaknanda by virtue of abundant Limnephilidae. The Bhagirathi was characterized by abundance of Philopot-amidae. Thus, assemblages exhibit greater variability in the Himalayan Rivers than Trans- Himalayan Rivers and are hence entirely different.

The cluster analysis reveals that the rivers of these two Himalayan zones (Himalaya and Trans-Himalaya) are different. Based on similarity in taxonomic composition, there is more similarity within rather than among the two ecoregions especially within Trans-Himalaya.

The association of the rivers of one zone can be explained through 'biome dependency hypothesis' (Ross, 1963; Corkum, 1989). This hypothesis predicts that similar assemblages of macroinvertebrate are most likely to occur at sites along river, if the drainage basin occupies the same biome. It seems that the dissimilarity of abundant fauna in the rivers of two different ecoregion is influenced by geographical factors i.e., terrain, latitude and soil type. The abundant taxon was not absolutely similar among the rivers of Himalaya unlike to Trans- Himalaya. Thus 'biome dependency hypothesis is applicable only to the Trans- Himalaya but not in the Himalaya. The reasons for this need further investigation. This present hypothesis is not applicable to explain the macro-invertebrate assemblages in Himalayan and TransHimalayan region.

\section{Acknowledgements}

The authors acknowledge the financial support in the form of research projects granted by Department of Science and Technology (DST), New Delhi and R.S. Envirolink Technologies Pvt. Ltd., Gurgaon, Haryana. Such wide scale studies could hardly be accomplished without financial support of desired magnitude. We thank Professor H.R. Singh, Vice Chancellor University of Allahabad, for his valuable suggestions and Prof. J.P. Bhatt, Head Department of Zoology, H.N.B. Garhwal University, Srinagar for the academic support.

\section{References}

Allan, J.D. 1959. The distribution of stream bottom fauna. Proc. New Zealand Ecol. Soc. 6: 5-8.

Badola, S.P. and H.R. Singh 1981. Hydrobiology of river Alaknanda of the Garhwal Himalaya. Indian J. Ecol. 8(2): 269-276.

Carter, J.C.H., M.J. Dadswell, J.C. Roff and W.G. Sprules 1980. Distribution and zoogeography of planktonic crustaceans and dipterans in glaciated eastern. North Am. Can. J. Zool. 58: 1355-1387.

Corkum, L.D. 1989. Patterns of benthic invertebrates assemblages in rivers of northwestern North America. Freshwat. Biol. 21: 191-205.

Cotta Ramusino, M., S. Villa and D. Calamari 1995. River continuum concept and correspondence analysis to study Alpine stream macro- 


\section{Asheesh Shivam Mishra, Prakash Nautiyal and Vijay Prakash Semwal \\ / Our Nature (2013) 11(1): 36-44}

invertebrate assemblage. Mem. lst. ital. Idrobiol. 53: $101-114$

Culp, J.M. and R.W. Davis 1982. Analysis of longitudinal zonation and river continuum concept in the Oldman-South Saskatchewan River system. Can. J. Fish. Aquat. Sci. 3: 12581266.

Cushing, C.E., C.D. Mclntire, K.W. Cumminsi, G.W. Minshall, R.C. Petersen, J.R. Sedell and R.L. Vannote 1983. Relationship among chemical, physical and biological indices along river continuum based in multivariarete analysis. Arch. Hydrobiol. 98: 317-326.

Edington, J.M. and A.G. Hildrew 1995. Caseless Caddis larvae of the British Isles. Freshwater Biological Association Scientific Publication, England, U.K. 133p.

Edmondson, W.T. 1959. Freshwater Biology. $2^{\text {nd }}$ edn. John Wiley and Sons, INC, New York. 1248p.

Engblom, E. and P.E. Lingdell 1999. Analysis of benthic invertebrates. In: River Jhelum, Kashmir Valley, impact on the aquatic environment (Ed. L. Nyman Swedmar). The International consultancy group of the national board of Fisheries, Göteborgs Länstryckeri AB, Sweden. pp. 39-75.

Gusain, O.P. 1994. Himalayan Mahseer - Ecological perspectives migration routes river Alaknanda. In: Mahseer The Game Fish (Ed. P. Nautiyal), Jagdamba Prakashan, Dehradun, India. pp. 147168.

Hynes, H.B.N. 1970. The ecology of running waters. Liverpool University Press, Liverpool. 555p.

Julka, J.M., H.S. Vasisht and B. Bala 1999. Distribution of aquatic insects in a small stream in north-west Himalaya India. J. Bombay Nat. Hist. Soc. 96(1): 55-62.

Khan, A.A. and S.K. Kulshrestha 1993. Benthic fauna in relation to pollution: a case study at river Chambal near Kota in Central India. Environ. Interna. 19: 597-610.

Kulshrestha, S.K., U.N. Adholia, A.A. Khan, A. Bhatnagar, M. Saxena and M. Baghail 1989 Community structure of plankton and macrozoobenthos with reference to pollution of river Khan, India. Intern. J. Env. Studies 35: 83-96.

Mishra, A.S. and P. Nautiyal 2013. Longitudinal distribution of benthic macro-invertebrate assemblages in a Central Highlands river, the Tons (Central India). Proc. Natl. Acad. Sci.,
India, Sect. B Biol. Sci. 83(1): 47-51. DOI 10.1007/s40011-012-0083-4

Mishra, A.S. and P. Nautiyal 2011. Factors governing longitudinal variation in benthic macroinvertebrate fauna of a small Vindhyan river in Central Highlands ecoregion (Central India). Trop. Ecol. 52(1): 103-112.

Mohan, M. and R.S. Bisht 1991. Taxo-ecology of aquatic entomo-fauna in freshwater ecosystem with special reference to river Bhagirathi and Bhilangana in Garhwal Himalaya. In: Ecology of the Mountain Waters (Eds. S.D. Bhatt and R.K. Pande). Ashish Publishing House, New Delhi. pp. 251-265.

Nautiyal, P. and A.S. Mishra 2012. Longitudinal distribution of benthic macro-invertebrate fauna in a Vindhyan river, India. Intern. J. Environ. Sci. 1(3): 150-158.

Nautiyal, P. and A.S. Mishra 2013. Variations in benthic macro-invertebratefauna as indicator of land use in the Ken river, Central India. Journal of Threatened Taxa 5(7): 4096-4105; http://dx.doi.org/10.11609/JoTT.o3211.4096-10.

Nautiyal, P., A. Shivam, G. Rawat, K.R. Singh, J. Verma and A.C. Dwivedi 2004. Longitudinal variation in the structure of benthic communities in the upland Vindhyan and Himalayan: River Continuum Concept approach. Nat. J. life Sci. I(1): 85-88.

Nautiyal, P., A. Shivam, J. Verma and V.P. Semwal 2007. Bhgirathi River - An endangered ecosystem. In: Proceeding of National Symposium on Limnology (Eds. B. Venkataramani, V.D. Puranik, S.K. Apte, H.N. Gour, S.K. Sharma, L.L. Sharma, V.S. Durve, H.C.L. Gupta, P.C. Verma and B.K. Sharma). Department of Aquaculture College of Fisheries, Udaipur, Rajasthan, February 19-21. pp. 164166.

Nautiyal, P., J.P. Bhatt, B. Kishor, V.S. Rawat, R. Nautiyal and H.R. Singh 1997. Assessment of fish food resource in relation to the migratory habits of Tor putitora (Ham) found in the impounded sections of the river Ganga between Rishikesh and Hardwar. Proc. Nat. Acad. Sci. India. Sect. 67(B) 3-4: 204-212.

Ormerod, S.J., S.D. Rundle, S.M. Wilkinson, G.P. Daly, K.M. Dal and I. Juttner 1994. Altitudinal trends in the diatoms, bryophytes, macroinvertebrates and fish of a Nepalese river 


\section{Asheesh Shivam Mishra, Prakash Nautiyal and Vijay Prakash Semwal / Our Nature (2013) 11(1): 36-44}

system. Freshwat. Biol. 32: 309-322."

Pahwa, D.V. 1979. Studies on the distribution of the benthic macro-fauna in the stretch of river Ganga. Indian J. Anim. Sci. 49(3): 212-219.

Pennak, R.W. 1953. Chapter 27 Ephemeroptera (Mayflies). Freshwater invertebrates of the United states. $2^{\text {nd }}$ edition. John Wiley and Sons, New York. pp. 512-733.

Ross, H.H. 1963. Stream communities and terrestrial biomes. Arch. Hydrobiol. 59: 235-245.

Semwal, V.P. and P. Nautiyal 2009. Spatial distribution patterns of benthic macroinvertebrate assemblages in the mountain streams: Mandakini basin-Gangetic Drainage of the western Himalayas. J. Hill Res. 22(1): 21-28.

Singh, H.R. and P. Nautiyal 1990. Altitudinal changes and the impact of municipal sewage on the community structure of macro-benthic insects in the torrential reaches of the river Ganges in the Garhwal Himalaya (India). Acta Hydrobiol. 32(314): 407-421.

Singh, H.R., P. Nautiyal, A.K. Dobriyal, R.C. Pokhriyal, M. Negi, V. Badoni, R. Nautiyal, N.K. Agarwal and A. Gautam 1994. Water quality of river Ganga (Garhwal Himalaya). Acta Hydrobiol. 36(1): 3-15.

Sivaramakrishnan, K.G., K. Venkataraman, S. Sridhar and U. Marimuthu 1995. Spatial patterns of benthic macro-invertebrate distribution along river Kaveri and its tributaries (India). Internat. J. Ecol. Environ. Sci. 21: 141-161.

Sunder, S. 1997. Biotic communities of Kumaon Himalaya river - The Gaula - 1. Macro-benthic invertebrates. Proc. Nat. Acad. Sci. India. Sect. 67(B) II: 157-167.

Vannote, R.L., G.W. Minshall, K.W. Cummins, J.R. Sedell and C.E. Cushing 1980. The river continuum concept. Can. J. Fish. Aquat. Sci. 37: 130-137.

Wallace, J.B. 1988. Aquatic invertebrate research. In: Forest, hydrology and ecology at Coweeta (Eds. W.T. Swank and D.A. Crossley). SpringrtVerlag, New York. pp. 257-268.

Ward, J.V. 1994. Ecology of alpine streams. Freshwater Biol. 32: 277-294.

Welcomme, R.L. 1985. Food and Agriculture Organization of the Unites Nations, Rome (Fisheries Technical Paper 262). 330p. 